\title{
Analysis of Hate Speech in Social Media on Indonesian Politics
}

\author{
Subyantoro $^{1}$, Muhammad Badrus Siroj ${ }^{2}$ \\ \{bintoro@mail.unnes.ac.id ${ }^{1}$, badrussiroj@mail.unnes.ac.id ${ }^{2}$ \} \\ Indonesian Language and Literature Education, Faculty of Languages and Arts, \\ Universitas Negeri Semarang, Indonesia
}

\begin{abstract}
Comments given by users or nitizens on social media such as Instagram are various. There are positive and negative ones. In the perspective of netizens, there is nothing wrong when they want to comment or express their hearth feeling. In Indonesia, if it is witnessed that the netizen's comments are negative, they often have to deal with the law and the police. This research will help people who want to send comments avoid containing negative content so that they can avoid crime in cyberspace. The method used in supporting this research is the K-Means method, to determine whether the comments are included into positive or negative categories. In this study, the data used were 40 comments as research objects
\end{abstract}

Keywords: hate speech, instagram, indonesian politics

\section{Introduction}

Social media is a medium that is used by individuals to become social, online by sharing content, news, photos and others with others [1]. From the definition that has been conveyed, it is clear that the public can share information and vice versa to the government. [2] defines online media as mass media which are presented online on the website of the Internet. Online media is "third generation" mass media after printed media — newspapers, tabloids, magazines, books and electronic media - radio, television, and film/video.

In the current era of Globalization, technological developments are increasingly sophisticated, fast and easy and are growing very rapidly throughout the world, including in Indonesia. Technological developments do not only have a positive impact, but also have a negative impact that triggers the emergence of various types of violations and even a crime [3]. Crime in human life is a social phenomenon that will always be faced by every human, society, and even the State. The Indonesian Telematics Society or Masyarakat Telematika Indonesia (Mastel) released a survey of fake information (hoax) which was rife in the country. From the results of the survey, it is revealed that social media is the main source of circulation of hoaxes.

In [4] that hate speech is a communication activity in individuals and groups in the form of incitement, provocation, insults directed at individuals and groups in various aspects. Like the news in [5] Jonru Ginting became a suspect because of cases of hate speeches. Jonru Ginting was thought to have uploaded a photo on his Facebook account that had nuanced hatred. In [6] Haidar became a suspect because he uploaded speeches of hatred to President Joko Widodo through his Instagram account. 
The role of language is very needed in order to arouse and foster human consciousness in creating and enforcing the law [7]. Speeches of legislative candidates are interesting to study because they are acts of socio-cultural practices which do not only have literal meaning, but also nonliteral meanings, or what is called [8] as natural meanings and unnatural meanings. Forensic linguistic studies link law with language as revealed by [9] that once a person tries to understand the signs he faces when reading a law or legal science literature, the person deals with language and thinking activities. Therefore, it can be understood that if someone is dealing with legal materials, then naturally it has to do with what is called language, thinking activities, and law. This means that all activities in the field of law such as the formation of legislation, court decisions, authentic deeds and other documents relating to the legal field are made and pronounced in legal language [10].

With some examples of the above cases, it is evident that the many negative impacts of technological development and not all information which is obtained has a positive effect on each reader. The development of technology known as the internet has changed the pattern of community interaction [11]. The progress of information technology especially in the online world has been used by the community as a tool to obtain information and other political interests. However, with the ease of creativity, many irresponsible parties take advantage of the opportunity for things that harm others. The community is expected to be wiser in utilizing social media. For example, first ensuring the accuracy of the content to be shared, clarifying the truth, ensuring its benefits, and then spreading it. The formulation of the problem in this research is how to utilize social media and minimize hoax information as a means to exchange information with the government.

One form of social media is Instagram [12]. Instagram is one of the web and mobilebased social media applications specifically used to upload images / photos. Instagram is a social media site that is increasingly being used mainly by Indonesian artists/actors. Instagram users will upload photos of their activities and then for each photo/image will be given a caption, tagging other Instagram accounts, the location where the photo was uploaded, edit photos shortly before uploading directly from the smartphone application, and certaVAVin hashtags so that the photo will be seen by more people. The Instagram application is developed for smartphones, both iOS, Android and Windows Phone platforms and is free. Web-based Instagram can be accessed at http://www.instagram.com.

One of the things that caused Instagram to be used is the ease of uploading photos directly from a smartphone, considering that social media users are mostly young people and really like selfies. However, in addition to these advantages, of course there are disadvantages that are quite disturbing, namely the number of comments that can be categorized as spam comments on a photo uploaded on Instagram. There are more and more spam comments on Instagram of famous artists / people because they have more followers.

From the background above, the focus of this research problem is the difficulty of distinguishing between false news and true news on Instagram. The formulation of the problem in this study is how the linguistic characteristics of hate speech on Instagram are.

\section{Research Method}

This study employed a linguistic approach with the theory of forensic linguistic theory. The methodological approach in this study used a qualitative approach. The focus of this research is the the hate speech in the 2019 presidential election campaign on Instagram. 
The data in this study are fragments that refer to meme sentences and comments on social media Instagram. The primary data sources in this study are Instagram content on @ prabowo and @jokowi accounts. Both of these accounts get very big attention from public during the 2019 presidential election.

The method of data collection is through scrutinizing (simak) and taking note (catat). It is called simak or scrutinizing because the method used by researchers aims to obtain data by scrutinizing the use of language in writing, while the method of taking notes (catat) is the method used to record important things and information and distinguish implicatures in the use of language. The method was done through identification of secondary data needed, inventory of data based on the formulation of the problem, citing literature related to research material.

\section{Result and Discussion}

In this section, the results of the analysis of research data are reported with the utterances of hate speech found on Instagram accounts of @ prabowo and @ jokowi.

\subsection{Analysis of Hate Speech on Instagram account @ prabowo}

Through Instagram, the owner of Prabowo's official account, on April 13, 2019 uploaded a photo with the following caption.

"Saya ucapkan terima kasih kepada partai koalisi adil makmur, seluruh relawan pendukung Prabowo - Sandi, para Emak-Emak, dan seluruh masyarakat yang tidak dapat saya sebutkan. Tidak lupa juga saya ucapkan kepada Calon Presiden dan Wakil Presiden Nomor urut 01 Bpk. Joko Widodo dan K.H Ma'ruf Amin, semoga Pemilihan Presiden kali ini dapat berjalan sesuai dengan keinginan rakyat, dan yang diberi mandate dapat menjalankan amanah yang diberikan oleh rakyat Indonesia."

"I express my gratitude to the Adil Makmur coalition party, all volunteers who support Prabowo - Sandi, Moms, and the whole community that I cannot mention. I also did not forget to thank to the Candidates of the President and Vice President Number 01 Mr. Joko Widodo and K.H Ma'ruf Amin. Hopefully, the Presidential Election this time can run according to the wishes of the people, and the ones who are given the mandate is able to carry out the mandate given by the people of Indonesia. " 


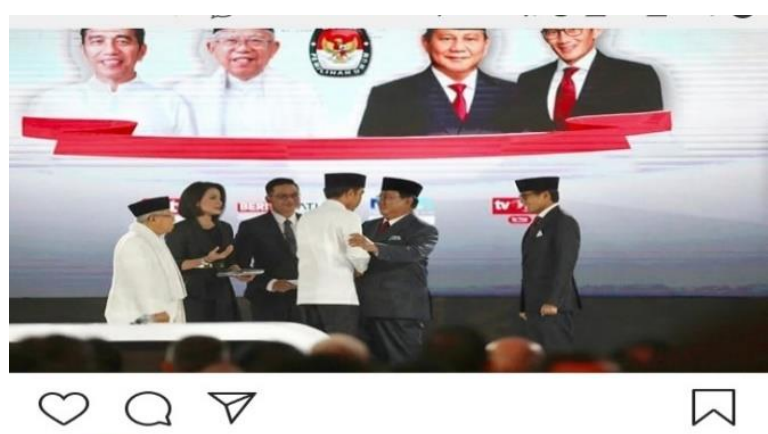

20.2 Disukai oleh setiyoppp dan 665.456 lainnya prabowo Saya ucapkan terima kasih kepada partai koalisi adil makmur, seluruh relawan pendukung Prabowo - Sandi, para Emak-Emak, dan seluruh masyarakat yang tidak dapat saya sebutkan. Tidak lupa juga saya ucapkan kepada pasangan Calon Presiden dan Wakil Presiden Nomor urut OI Bpk. Joko Widodo dan K.H Maaruf Amin, semoga Pemilihan Presiden kali ini dapat berjalan sesuai dengan keinginan rakyat, dan yang diberi mandat dapat menjalankan amanah yang diberikan oleh rakyat Indonesia.

Lihat semua 17.270 komentar

13 April

\section{$\triangle \quad Q \quad \oplus \quad 0 \quad$}

In the upload statemet, there were several comments containing hate speech, including the following:

Comment endal50: "\#mhmmad.aviv semua orng jg tau prabondut sombong songong emosianal sok tau tp ga punya wibawa dan ga pantas jd pemimpin bangsa kita liat buktinya bersama, tolong buta mata lu dan be smart dikit lu"

[Everyone also knows that the fat Prabowo is arrogant, emotional, as if he knows everything, but he has no authority and it is inappropriate for our nation's leaders. Let's see the evidence together, please open your eyes and be a little smart.]

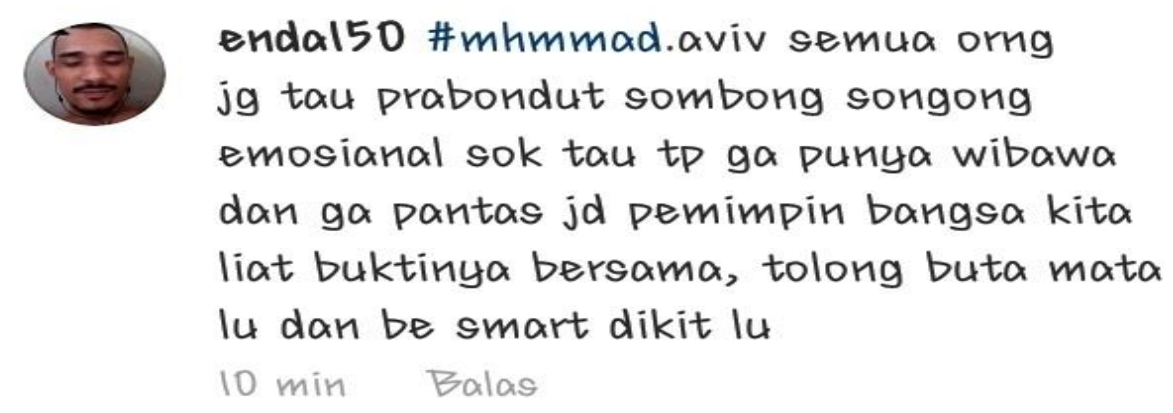

\section{a. Lexical Semantic Analysis}

The words expressed by account endal50 are "prabondut", "sombong", "songong", and "emosional". The word "prabondut" is the acronym of Prabowo Gendut. The word "gendut" 
in KBBI V Online Edition means big and it looks hanging (about stomach); pregnant (puffed up).

The next word is "sombong". In KBBI V Online edition, it means value ourselves in exces; arrogant; boastful. The third word is "songong". In KBBI V Online Edition, it means not customary. The last word is "emosional". In KBBI V Online Edition, it means with emotion; emotion; full of emotion. From the use of these words according to lexical analysis, it contains negative connotations and is degrading.

\section{b. Grammatical Semantic Analysis}

Grammatically, there are three sentences, namely "semua orng jg tau prabondut sombong songong emosianal sok tau tp ga punya wibawa dan ga pantas jd pemimpin bangsa [Everyone also knows that the fat Prabowo is arrogant, emotional, as if he knows everything, but he has no authority and it is inappropriate for our nation's leaders]", "kita liat buktinya bersama, tolong buta mata lu dan be smart dikit lu [Let's see the evidence together, please open your eyes and be a little smart]". The speech "semua orng jg tau prabondut sombong songong emosianal sok tau tp ga punya wibawa dan ga pantas jd pemimpin bangsa" is an equivalent compound sentence. The sentence consists of six sentences, namely (1) "asemua orng jg tau prabondut sombong", (2) "semua orng jg tau prabondut songong", (3) "semua orng jg tau prabondut emosional", (4) "semua orng jg tau prabondut sok tau", (5) "semua orng jg tau prabondut ga punya wibawa", dan (6) "semua orng jg tau prabondut ga pantas jd pemimpin bangsa". All of these sentences refer to one subject, Prabowo. The sentence "tolong buta mata lu dan be smart dikit lu " is a multilevel compound sentence, which is "tolong buta mata lu" (the word "buta/blind" here is a form of typo that should be "buka" or open instead of being blind) and "be smart little lu". The sentence was not addressed to Mr. Prabowo but to mhmmad.aviv whose meaning was a request for mhmmad.aviv to open his eyes and be smart by not choosing Prabowo because of the things mentioned in the previous sentence. The lexical and grammatical analysis show that the distended Prabowo has bad qualities (arrogant, songong, emotional, as if knows everything, not authoritative) so that it is not appropriate to be a leader of the people. This has been already known to everyone.

\section{c. Pragmatic Analysis}

The sentence that was stated by endal50, namely "semua orng jg tau prabondut sombong songong emosianal sok tau tp ga punya wibawa dan ga pantas jd pemimpin bangsa" is a provocative expressive speech act. In the sentence, endal50 expressed his disappointment and anger at "Prabowo". The phrase "kita liat buktinya bersama [we see the proof together]" is a form of challenging directive speech act. Here endal50 challenges "Prabowo" to prove all his words. The sentence "tolong buka mata lu dan be smart dikit lu " is a form of provocative directive speech act. In the endal50's sentence, this shows an invitation and provocation to mhmmad.aviv to open his eyes and be smart.

\subsection{Analysis of Hate Speech on Instagram Account @jakowi}

Through Instagram, the owner of Jokowi's official account writes the caption along with the link associated with the post. 


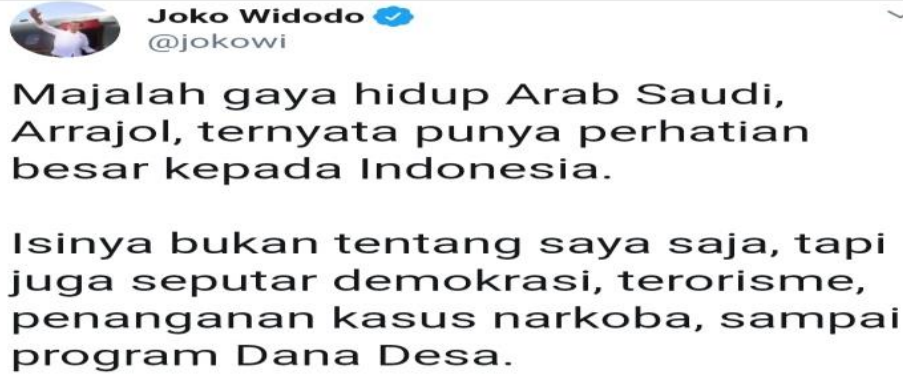

Komentar ERWIN TAMBARUKA@BlackDe1: "\#PEMBOHONG BICARA BAHASA INGGRIS SJA BLEPOTAN

NGAJI TAU APA NGGA

APALAGI MAU MEMBACA MAJALAH ARAB"

[“\#LIAR

SPEAKING BAD ENGLISH

DOES NOT KNOW QURAN RECITATION

MOREOVER YOU WANT TO READ ARABIC MAGAZINE"

'\#LIAR]

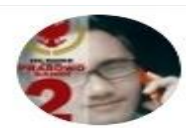

ERWIN TAMBURAKA

@BlackDe1....38m

Replying to@jokowi

\#PEMBOHONG 조용

BICARA BAHASA INGGRIS SJA BLEPOTAN

NGAJI TAU APA NGGA

APALAGI MAU MEMBACA MAJALAH ARAB

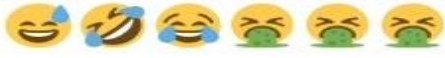

Q

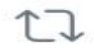

2

a. Lexical Semantic Analysis

The words "PEMBOHONG" and "BLEPOTAN" are used in discussions by ERWIN TAMBARUKA @BlackDe1 containing lexical meanings. In KBBI V Daring Edition, it is stated that the meaning of the word "pembohong (liar)" is a person who likes to lie (lie) and the word "blepotan" is a non-standard form of smear which is wallowing (with mud); muddy. Thus, the lexical meaning contained in these words shows the negative and low connotations..

b. Grammatical Semantic Analysis

ERWIN TAMBARUKA @BlackDe1 wrote “\#PEMBOHONG, BICARA BAHASA INGGRIS SJA BLEPOTAN. NGAJI TAU APA NGGA. APALAGI MAU MEMBACA MAJALAH ARAB" consists of three sentences, namely (1) "\#PEMBOHONG, BICARA BAHASA INGGRIS SJA BLEPOTAN", (2) "NGAJI TAU APA NGGA", dan (3) "APALAGI MAU MEMBACA MAJALAH ARAB". The object of the speech is President Jokowi. 
The first sentence is grammatically meaning that President Jokowi is a liar who, when speaking English, is still bad (not smooth). The second sentence is a question of whether President Jokowi can recite. The third sentence is meaningful indeed, President Jokowi can read Arabic magazines.

\section{c. Pragmatic Analysis}

In the pragmatic study, the whole sentence written by ERWIN TAMBARUKA @ BlackDe1 account owner is included in the provocative expressive speech act. In this article, ERWIN TAMBARUKA @ BlackDe1 showed disappointment and anger towards President Jokowi who, according to him, was embarrassing with his weak English skills.

Based on the comment data on the two accounts which are the data of this research, the following results are obtained.

Tabel 1. Realization of Hate Speech on Instagram

\begin{tabular}{cllr}
\hline No & Type of Hate Speech & Frequency & Percentage \\
\hline 1. & Insulting & 8 & $20,00 \%$ \\
\hline 2. & Defamation & 10 & $25,00 \%$ \\
\hline 3. & Blasphemy & 7 & $17,50 \%$ \\
\hline . & Unpleasant acts & 5 & $12,50 \%$ \\
\hline 5. & Provocation & 6 & $15,00 \%$ \\
\hline 6. & Incitement & 4 & $10,00 \%$ \\
\hline 7. & Distribution of false news & 0 & $0,00 \%$ \\
\hline
\end{tabular}

Based on the data in Table 1, it can be seen that the realization of hate speech which is the highest is in the form of defamation (25\%), followed by humiliation (20\%), defamation $(17.5 \%)$, provocation $(6 \%)$, unpleasant actions $(12.5 \%)$, incitement $(10 \%)$, and dissemination of false news $(0 \%)$.

Based on the realization of linguistic units in hate speech, the results of the study are as follows.

Table 2. Instagram Realization of Linguistic Unit of Hate Speech on Instagram

\begin{tabular}{rllc}
\hline N & Linguistic Unit of Hate Speech & Frequency & Percentage \\
\hline 1. & Word & 8 & $20,00 \%$ \\
\hline . & Phrase & 15 & $37,50 \%$ \\
3. & Clause & 8 & $20,00 \%$ \\
4. & Sentence & 6 & $15,00 \%$ \\
5. & Discourse & 3 & $7,50 \%$ \\
\hline & Total & 40 & $100,00 \%$ \\
\hline
\end{tabular}

Based on the research data in table 2, it can be seen that hate speech in the form of phrases is $37.5 \%$, in the form of words and clauses is $20 \%$, in the form of sentences is $15 \%$, and the least in the form of discourse is $7.5 \%$. 


\section{Conclusion}

Based on the results of the research and discussion, it can be concluded that the realization of hate speech in the form of insultation, defamation, blasphemy, unpleasant acts, provocation, incitement, and the distribution of false news. Meanwhile, based on the linguistic form of hate speech can be expressed in the form of words, phrases, clauses, sentences, and in the form of discourse.

\section{References}

[1] Aliandu, P., Analisis Sentimen Tweet Berbahasa Indonesia di Twitter, Tesis, Universitas Gadjah Mada, Yogyakarta, 2012.

[2] Anna, Lusia Kus. Instagram, Media Sosial Paling Buruk bagi Kesehatan Mental. https://lifestyle.kompas.com/read/2017/07/14/073913720/instagram-media-sosial-paling-buruk-bagikesehatan-mental. Diakses: 15 Mei 2018, jam 20.05.

[3] Abidin, Zainil, Teguh Bharata Adji, dan Hanung Adi Nugroho, System of Negative Indonesian Website Detection Using TF-IDF and Vector Space Model, IEEE International Conference on Electrical Engineering and Computer Science, 2014.

[4] Criminal justice Act 2003. [Online]. Available: http://legislation.gov.uk/ ukpga/2003/44/section/ 146. 2003.

[5] Modus Ujaran Kebencian Jonru Ginting Sama Seperti Saracen. [Online]. Available: www.liputan6.com . 2017.

[6] Polisi Tangkap Haidar, Pelaku ujaran Kebencian Lewat Instagram. [Online]. Available: https://kriminologi.id/hard-news/cyber-crime/polisitangkap-haidar-pelaku-ujaran-kebencian-lewatinstagram, 2017.

[7] Subyantoro, Linguistik Forensik: Sumbangsih Kajian Bahasa dalam Penegakan Hukum. ADIL INDONESIA JURNAL VOLUME 1 NOMOR 1, JANUARI 2019.

[8] Grice, H.P, "Meaning". The Philosophical Review, volume 67, Durham: Duke University Press. hlm. 385, 1957.

[9] Gibbons, J, "Forensic Linguistics: an introduction to language in the Justice System", Blackwell, 2007.

[10] Ardiansyah, Ghazali, M.I., Pengujian Usability User Interface Dan User Experience Aplikasi EReader Skripsi Berbasis Hypertext, Jurnal Ilmiah Teknologi Informasi Terapan, Vol.2, 2016.

[11] Dan, Li, dkk., Research of Text Categorization on WEKA, Third International Conference on Intelligent System Design and Engineering Applications, 2013.

[12] Lusia Kus Anna. Instagram, Media Sosial Paling Buruk bagi Kesehatan Mental, https://lifestyle.kompas.com/read/2017/07/14/073913720/instagram-media-sosial-paling-buruk-bagikesehatan-mental. Diakses: 20 Mei 2018, jam 19.30. 